\title{
The Effect of Citrus Pulp Amendment on Sunflower Production and the Dissipation of the Herbicide Aclonifen
}

\author{
Cristina Abbate ${ }^{* 1}$, Rosalena Tuttobene ${ }^{1}$, Giovanni Avola ${ }^{2}$, Mara Gennari ${ }^{1}$ \\ ${ }^{1}$ Dipartimento di Scienze Agronomiche, Agrochimiche e delle Produzioni animali \\ University of Catania, via Valdisavoia 5, 95100 Catania, Italy \\ ${ }^{2}$ UOS Colture erbacee ISAFoM-CNR \\ Via Valdisavoia 5, 95100 Catania, Italy
}

Received: 13 March 2007. Accepted: 10 June 2007

\begin{abstract}
The research evaluated the effects that amendment with $3 \mathrm{~kg} \mathrm{~m}^{-2}$ and $9 \mathrm{~kg} \mathrm{~m}^{-2}$ of citrus pulp had both on the production of sunflowers and the dissipation of the aclonifen herbicide. At the same time any eventual effect of the use of the herbicide on sunflower production was verified. The use of the citrus pulp determined an increase in the height of the plants, the diameter of the flower-heads and their achenes production and a reduction in the sterile zone. The effect of amending was not proportional to the quantity of citrus pulp added: in fact, the maximum agronomic efficiency was reached with the lowest quantity of amendant $(97 \mathrm{~kg}$ of achenes per ton of citrus pulp used, as against the $53 \mathrm{~kg}$ obtained with the higher quantity). The herbicide had no effect on sunflower production. The dissipation of aclonifen was not influenced by the addition of citrus pulp in field conditions but in laboratory conditions a faster degradation was found. The mean half-life time was 14 days in the field and 30 and 13 days respectively, in untreated soil and soil treated with citrus pulp, in laboratory conditions.
\end{abstract}

Key-words: aclonifen dissipation, citrus pulp, sunflower.

\section{Introduction}

The use of food industry by-products as agricultural amendants is not only an environmentally friendly and economical solution to the problem of their disposal. It can also contribute to solving the problem of the limited amount of organic matter in the agricultural lands of the semiarid areas of the Mediterranean basin countries. In effect, in these soils the degradation of organic matter is much greater than is the humification process, due to high temperatures and high soil oxygen content which lead to a high mineralization; to which should be added an increasingly scarce supply of organic matter.

Some research projects have confirmed the possibility of using citrus pulp as amendant (Correia Guerriero and Carrasco de Brito, 1995; Avola et al., 2004; Belligno et al., 2005). This amendant, having an acid reaction and being rich in organic carbon and nitrogen, has posi- tive effects on the physical and chemical characteristics of the soil, besides representing a source of energy for soil microorganisms, with a consequent increase in microbial biomass and its activity (Garcìa et al., 2000).

With reference to the effects of this organic amendant on crop growth and production, previous research demonstrated a stimulating effect on wheat growth but also confirmed that high doses had a depressive effect on grain yield (Belligno et al., 2005); in lettuce crops, positive effects on the production of fresh and dry biomass were found (Correia Guerriero and Carrasco de Brito, 1995).

Sunflowers are not widely cultivated in southern Italy due to the arid conditions which are typical of the spring-summer period; nonetheless, considering the scarcity of soil-improving rotation crops, a more widespread cultivation would be desirable. To attain this objective it would be possible to use both winter sowing (Anastasi et al., 2000), and amendment 
with organic matter, due to the positive effects of the latter on soil porosity and, therefore, on soil water retention capacity.

In semiarid areas, it is necessary to control weeds which compete for water resources, especially with crops like sunflowers where there are wide spaces between the rows. However, the behaviour of herbicides in soils can be modified by organic amendment, depending on the nature of the organic matter and the characteristics of the herbicide itself. A reduction in the leaching and degradation of the herbicides was noted due to its increased adsorption (Bellin et al., 1990; Baskaran et al., 1996). On the other hand some amendants contains soluble organic matter with a consequent increase in the solubility of the herbicide and its desorption (Abdul et al., 1990; Celis et al., 1998). Among the different herbicides used on sunflowers, aclonifen has been shown to be one of the most effective (Covarelli, 1999; Vischetti et al., 2002).

Aclonifen (2-chloro-6-nitro-3-phenoxyaniline) is a selective herbicide used for pre-emergence residual weed control of a wide spectrum of annual broadleaf weeds and grasses in sunflower, corn, tobacco cultivation and numerous horticultural crops.

Information regarding the behaviour of aclonifen in the soil is limited. Vischetti et al. (2002) carried out laboratory and field tests to verify the degradation and leaching of aclonifen in the soil. In the laboratory studies the herbicide showed $\mathrm{DT}_{50}$ of between 40.3 and 49.1 days depending on temperature and soil moisture. Kept in lisimeters in field conditions the aclonifen reached a maximum depth of $30 \mathrm{~cm}$ when greatly irrigated. Trevisan et al. (1999) carried out degradation tests on aclonifen in the soil, evaluating the effects of both moisture and temperature. The Authors found that the water content of the soil had a considerable effect on the rate of degradation which was lower when there was low moisture, while they found that the temperature had a less marked effect, an increase of $20{ }^{\circ} \mathrm{C}$ reducing the $\mathrm{DT}_{50}$ of only 8 days.

The aim of this research was to study the effects of citrus pulp soil amendment on sunflower production and on the degradation of aclonifen. At the same time the effect of the herbicide on crop yield was also evaluated.

\section{Materials and methods}

\subsection{Chemicals}

The aclonifen (98\% pure) came from Erhenstorfer (Ausberg, Germany). The technical aclonifen (Challenge $49 \%$ a.i.) came from Rhône-Pouleng. All the other chemicals used were analytical reagents or HPLC grade.

\subsection{Soil}

A sandy loam soil was used for both field and laboratory studies. It contained $11.7 \%$ clay, had a CEC of 12.3 mequiv/100g. and an organic matter content of $0.78 \%$, while its $\mathrm{pH}$ in water (1:2.5 ratio) was 8.0 and its maximum water holding capacity (MWHC) was $35.3 \%$ of its dry weight.

\subsection{Citrus pulp}

The citrus pulp came from a citrus fruit processing factory in Caltagirone (Catania) and was air dried for six months before being used. The chemical analyses relating to the characterisation of the citrus pulp were carried out following the methods for compost analysis laid down by the Assessorato all'Ambiente of Piedmont Region (1998).

The citrus pulp had a sub-acid reaction (5.9) and contained a high amount of oxidizable organic C (41\%) and total N $(2.8 \%)$ in agreement with that found by various authors in unstabilised citrus fruit industry residues (Correia Guerriero and Carrasco de Brito, 1995; Alianello and Baroccio, 2001). The $\mathrm{C} / \mathrm{N}$ ratio (14.6) was similar to that of urban, solid waste compost (Garcìa et al., 1992), and very similar to that usually found in agricultural soil (10-12).

\subsection{Field studies}

The experimental testing was carried out with random plot schemes, using $0.9 \mathrm{~m} \times 0.9 \mathrm{~m} \times 0.5$ $\mathrm{m}$ height/depth lisimeters maintained in field conditions. The experimental area had a sub-humid - humid climate (annual rainfall $684 \mathrm{~mm}$ : annual average temperature $18^{\circ} \mathrm{C}$ ) according to the Thornthwaite global humidity index (Cartabellotta et al., 1998).

The following soil conditions were tested: 1 ) unamended soil without chemical weed control (A), and unamended soil with chemical weed control $\left(\mathrm{A}_{1}\right) ; 2$ ) soil amended with $3 \mathrm{~kg} \mathrm{~m}^{-2}$ of citrus pulp without chemical weed control (B) and soil amended with $3 \mathrm{~kg} \mathrm{~m}^{-2}$ of citrus pulp 
with chemical weed control $\left.\left(\mathrm{B}_{1}\right) ; 3\right)$ soil amended with $9 \mathrm{~kg} \mathrm{~m}^{-2}$ of citrus pulp without chemical weed control (C) and soil amended with 9 $\mathrm{kg} \mathrm{m}^{-2}$ of citrus pulp with chemical weed control $\left(\mathrm{C}_{1}\right)$.

Three repeat tests were performed for each treatment.

The citrus pulp was introduced into the soil in October 2005. Before being covered over at a depth of 0-30 cm, the material was reduced to pieces of between 0.5 and $10 \mathrm{~mm}$ diameter.

The sunflowers were sown on 7 April 2005 (Gloriasol hybrid variety), with a density of 6 plants per $\mathrm{m}^{2}$. The plants were regularly watered for the whole of the period of cultivation so that water would not constitute a limiting factor. For pre-emergence chemical weed control, technical aclonifen (Challenge $49 \%$ a.i.) was distributed at the recommended dose of $1.0 \mathrm{~kg} \mathrm{ha}^{-1}$. Five soil cores $(25.0 \mathrm{~cm}$ length, $5.8 \mathrm{~cm}$ diameter) were taken from each plot using a continuous sampling tube which fits into an electrical hollow-stem auger column, 0, 7, 16, 28, 60 and 120 days after the treatment. Samples for each plot were mixed, sieved through a $2 \mathrm{~mm}$ mesh sieve and immediately frozen at $-25{ }^{\circ} \mathrm{C}$ until analysis.

During the biological cycle of the crop the dates of the main phenological phases (emergence, start of flowering, physiological maturity) were determined; when the seeds reached physiological maturity the height of the plant, the diameter of the flower-head, the diameter of the sterile zone, the number of achenes per flower-head and their overall weight were determined.

Moreover, the agronomic efficiency index (AE) of the citrus pulp was calculated using the formula: $A E=\left(R_{p x}-R_{p 0}\right) / P_{x}$, where $R_{p 0}$ represents the achenes production with no amendment and $R_{p x}$ the achenes production with $x$ citrus pulp added; Px was the amount of citrus pulp added (Mariotti et al., 2000).

\subsection{Laboratory studies}

The soils used for the laboratory experiments were sampled to a depth of $0-25 \mathrm{~cm}$ from plots $\mathrm{A} 1$ and $\mathrm{C} 1$ after amendment and prior to application of the herbicide. After collection, the soils were dried to $10 \%$ water content (w/w), sieved to obtain a $<2 \mathrm{~mm}$ fraction and stored at $4{ }^{\circ} \mathrm{C}$ until use.

The soils were incubated in closed systems based on that described by Laskowsky et al. (1983). Each incubation system consists in an apparatus with two compartments. The soil sample (50 g dry weight) was placed in the first compartment and $75 \mathrm{ml}$ of $0.05 \mathrm{~N} \mathrm{NaOH}$ was placed in the second one to trap the carbon dioxide produced by the respiration process. The systems were connected to an oxygen supply to replace the oxygen consumed.

Aclonifen was added to soils at $4 \mu \mathrm{g}^{-1}$ dry soil as an aqueous solution. Soil moisture was adjusted to $50 \%$ of WHC. The closed system maintains the desired soil moisture throughout the experiment (Gennari et al., 1986). Incubation was conducted in the dark at $25^{\circ} \mathrm{C}$. Three individual incubation systems were removed at $0,7,14,28,56$, and 91 days and analyzed for aclonifen residual concentration.

\subsection{Aclonifen analysis}

The soil samples were transferred to $250 \mathrm{ml}$ polyethylene bottles and extracted with $80 \mathrm{ml}$ of water:methanol 50:50 (v/v), shaken for 30 minutes, then centrifuged for 10 minutes at 3000 $\mathrm{rpm}$. The supernatant was collected in a $500 \mathrm{ml}$ separatory funnel. This procedure was repeated three times on the same sample. The combined extracts were partitioned in dichloromethane (3 x $50 \mathrm{ml}$ ); the organic phase was dried by filtration over anhydrous sodium sulphate and evaporated to dryness in a rotary evaporator. The residue was dissolved in acetonitrile:water acidified to $\mathrm{pH} 3$ with $\mathrm{H}_{3} \mathrm{PO}_{4}$ 70:30 (v/v). The samples were filtered on $0.45 \mu \mathrm{m}$ nylon membrane, then analysed by LC using a Perkin Elmer Mod LC 250 Liquid Chromatograph equipped with a Perkin Elmer Mod LC 235 diode array detector operating at $314 \mathrm{~nm}$ and a rheodyne valve (10 $\mu$ l loop). The separation was performed on a C 18 column (Merck Lichrospher 100 RP-18, $10 \mu \mathrm{m}, 25 \mathrm{~mm} \times 4 \mathrm{~mm}$ ); the composition of the eluent was $30 \%$ water acidified to $\mathrm{pH} 3$ with $\mathrm{H}_{3} \mathrm{PO}_{4}$ and $70 \%$ acetonitrile at a flow of $1 \mathrm{ml}$ $\mathrm{min}^{-1}$. The recovery was $94 \% \pm 2$.

\section{Results and discussion}

\subsection{Degree of infestation}

The degree of infestation expressed as the number of weeds per surface unit, proved to be totally insignificant $(<10 \%)$ even when no chemi- 
Table 1. Main phenological stages duration. $\mathrm{A}$ and $\mathrm{A}_{1}=\mathrm{un}$ amended soils; $\mathrm{B}$ and $\mathrm{B} 1=$ soils amended with $3 \mathrm{Kg} \mathrm{m}^{-2}$ of citrus pulp; $\mathrm{C}$ and $\mathrm{C}_{1}=$ soils amended with $9 \mathrm{Kg} \mathrm{m}^{-2}$ of citrus pulp.

\begin{tabular}{lcccc}
\hline Treatments & Emergence $\begin{array}{c}\text { From } \\
\text { sowing to } \\
\text { beginning } \\
\text { of the } \\
\text { flowering } \\
\text { days }\end{array}$ & $\begin{array}{c}\text { Physiological } \\
\text { maturity }\end{array}$ \\
\hline Without weed & $\mathrm{A}$ & 7 & 85 & 107 \\
control & $\mathrm{B}$ & 7 & 76 & 108 \\
& $\mathrm{C}$ & 7 & 75 & 107 \\
With weed & $\mathrm{A}_{1}$ & 7 & 86 & 108 \\
control & $\mathrm{B}_{1}$ & 7 & 77 & 109 \\
& $\mathrm{C}_{1}$ & 7 & 76 & 108 \\
\hline
\end{tabular}

cal control was carried out. The absence of an early infestation and the great luxuriance of the crop vegetation, which covered the spaces between the rows, prevented weeds from spreading.

\subsection{Biological cycle and morpho-biometric char- acteristics}

The variance analysis, which the main morphobiometric and productive characteristics underwent, made it possible to observe significant differences only as regards the quantities of citrus pulp added. Therefore, the averages of the data for each sample, both with and without weed control, are given for the letters A, B and C.

The biological cycle (emergence - maturity) lasted 108 days on average, with no differences as regards the treatments studied (Tab. 1). Taking an average from the two quantities of citrus pulp added, flowering began about 10 days earlier in the amended soil as compared to the unamended soil (Tab. 1). The addition of the citrus pulp determined an increase in plant height which increased with the quantity but not proportionally to the quantity $(+32 \%$ between plots $\mathrm{A}$ and $\mathrm{B}$ and $7 \%$ between $\mathrm{B}$ and $\mathrm{C}$ ) (Tab. 2). The height reached, with the highest quantity, was equal to $180.5 \mathrm{~cm}$ on average, the same value as recorded in field tests with spring sowing in a Mediterranean environment (Anastasi et al., 2000).

The effect of the amendment had an even more noticeable result on the diameter of the flower-head, which increased by $96 \%$ and $146 \%$ in plots $\mathrm{B}$ and $\mathrm{C}$ respectively as compared to plots A (Tab. 2). In this case too, the increase was not proportional to the quantity of citrus pulp added to the soil in that the difference between plots B and C was only $25 \%$. Vice-versa, the citrus pulp determined, on average in the two quantities, a significant reduction in the diameter of the sterile zone (Tab. 2).

\subsection{Production of dry biomass and achenes}

With regard to dry biomass, as the quantity of compost increased this determined an increase in the total dry weight of the plant, which first tripled (between A and B) and then more or less redoubled (between $B$ and $C$ ). Increases of the same kind were found for the dry weight of the flower-head (Tab. 3).

The seed yield also increased with an increase in the quantity, with successive increases equal to about 5 times between sample A (0.6 $\left.\mathrm{t} \mathrm{ha}^{-1}\right)$ and $\mathrm{B}\left(3.2 \mathrm{t} \mathrm{ha}^{-1}\right)$ and twice between $\mathrm{B}$ and $\mathrm{C}\left(5.5 \mathrm{t} \mathrm{ha}^{-1}\right)$. An analysis of the yield components confirms the production result exactly (Tab. 3). The maximum production found (5.5 $\mathrm{t}$ $\mathrm{ha}^{-1}$ ), was high if compared to the levels of production observed in tests carried out in lisimeter in a Mediterranean environment (Katerji et al., 2003; Kahlown et al., 2005), and comparable to levels produced in the field (Anastasi et al., 2000; Anastasi et al., 2001).

However, unlike the results found by Belligno et al. (2005) for wheat, no depressive effect on achenes production was observed at higher quantities, although in both cases luxuriant vegetation was seen.

Table 2. Sunflowers morpho-biometric characteristics. A and $\mathrm{A}_{1}=$ unamended soils; $\mathrm{B}$ and $\mathrm{B}_{1}=$ soils amended with $3 \mathrm{Kg}$ $\mathrm{m}^{-2}$ of citrus pulp; $\mathrm{C}$ and $\mathrm{C}_{1}=$ soils amended with $9 \mathrm{Kg} \mathrm{m}^{-2}$ of citrus pulp. LSD values at $\mathrm{P}<0.05$; ns $=$ not significant.

\begin{tabular}{lcccc}
\hline Treatments & & $\begin{array}{c}\text { Stem } \\
\text { length }\end{array}$ & $\begin{array}{c}\varnothing \text { Flower } \\
\text { head }\end{array}$ & $\begin{array}{c}\varnothing \text { No-fertile } \\
\text { area }\end{array}$ \\
\hline Without weed & $\mathrm{A}$ & 128 & $\begin{array}{c}(\mathrm{cm}) \\
8.0\end{array}$ & 3.0 \\
control & $\mathrm{B}$ & 169 & 15.7 & 1.7 \\
& $\mathrm{C}$ & 182 & 19.7 & 0.7 \\
With weed & $\mathrm{A}_{1}$ & 129 & 8.0 & 3.0 \\
control & & & & \\
& $\mathrm{B}_{1}$ & 170 & 15.7 & 1.3 \\
LSD & $\mathrm{C}_{1}$ & 179 & 19.7 & 1.7 \\
Amendment & & 7.7 & 1.4 & 0.8 \\
Weed control & & $\mathrm{ns}$ & $\mathrm{ns}$ & $\mathrm{ns}$ \\
Interaction & & $\mathrm{ns}$ & $\mathrm{ns}$ & $\mathrm{ns}$ \\
\hline
\end{tabular}


Table 3. Sunflower production. $\mathrm{A}$ and $\mathrm{A}_{1}=$ unamended soils; $\mathrm{B}$ and $\mathrm{B}_{1}=$ soils amended with $3 \mathrm{Kg} \mathrm{m}^{-2}$ of citrus pulp; $\mathrm{C}$ and $\mathrm{C}_{1}=$ soils amended with $9 \mathrm{Kg} \mathrm{m}^{-2}$ of citrus pulp. LSD values at $\mathrm{P}<0.05$; $\mathrm{ns}=$ not significant.

\begin{tabular}{|c|c|c|c|c|c|c|}
\hline Treatments & & $\begin{array}{l}\text { Stem dry weight } \\
\text { dry weight } \\
(\mathrm{g})\end{array}$ & $\begin{array}{c}\text { Flower-head } \\
\text { dry weight } \\
\text { (g) }\end{array}$ & $\begin{array}{l}1000 \text { seed } \\
\text { weight } \\
(\mathrm{g})\end{array}$ & $\begin{array}{c}\text { Achenes } \\
\text { (n) }\end{array}$ & $\begin{array}{l}\text { Seed yield } \\
\left(\mathrm{t} \mathrm{ha}^{-1}\right)\end{array}$ \\
\hline \multirow{3}{*}{ Without weed control } & $\mathrm{A}$ & 98.3 & 58.5 & 21.3 & 573 & 0.7 \\
\hline & $\mathrm{B}$ & 224.0 & 205.0 & 36.4 & 1464 & 3.2 \\
\hline & $\mathrm{C}$ & 396.7 & 307.0 & 48.1 & 1852 & 5.3 \\
\hline \multirow[t]{3}{*}{ With weed control } & $\mathrm{A}_{1}$ & 94.5 & 54.7 & 21.2 & 413 & 0.5 \\
\hline & $\mathrm{B}_{1}$ & 227.2 & 207.6 & 40.4 & 1264 & 3.1 \\
\hline & $\mathrm{C}_{1}$ & 321.6 & 314.6 & 44.0 & 2136 & 5.6 \\
\hline \multicolumn{7}{|l|}{ LSD } \\
\hline Amendment & & 40.1 & 11.4 & 1.5 & 137.1 & 0.4 \\
\hline Weed control & & ns & ns & ns & ns & ns \\
\hline Interaction & & ns & ns & ns & ns & ns \\
\hline
\end{tabular}

\subsection{Agronomic efficiency of the citrus pulp}

The AE of the citrus pulp (achenes production per ton of citrus pulp added) was found to diminish as the quantity increased (97 kg to 53 $\mathrm{kg}$ ). The greater efficiency of a lower quantity was also observed in wheat (Belligno et al., 2005).

\subsection{Dissipation of aclonifen in the field}

The results for aclonifen dissipation in the field study are reported in Figure 1. No differences in the rate of dissipation of the herbicide were found between the three experimental conditions. The mean $\mathrm{DT}_{50}$ was 14 days and the mean quantity found after 120 days from application was $0.3 \%$ of the initial amount. In all cases, there was a first-order degradation kinetics with $\mathrm{r}^{2}$ values above $0.98 \%$. This result suggests that, in field conditions, the addition of compost does not influence either the bioavailability of the molecule or the biodegradation process which should be stimulated by the increase in microbial activity following on from the addition of the organic matter (Meli et al., 2007).

Our results differ from those found by Trevisan et al. (1999) who showed a greater persistence of the herbicide in field conditions $\left(\mathrm{DT}_{50}=56.7\right.$ days $)$. After a $40 \%$ decrease in the concentration of aclonifen in the first four days, Trevisan et al. (1999) observed a stop in the dissipation for 57 days after which the process started again and reduced the concentration of the herbicide to $10 \%$ of the initial dose 174 days after treatment. The difference between what was found in our experiment as compared to

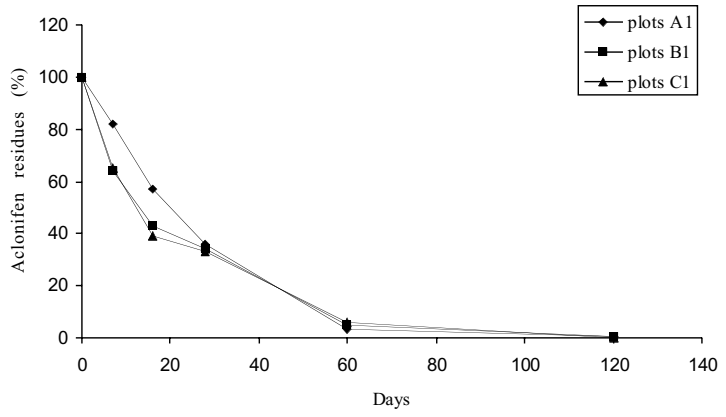

Figure 1. Degradation kinetics of aclonifen in amended and unamended soils: field test. Plots A1 = unamended soil; plots $\mathrm{B} 1=$ soil amended with $3 \mathrm{Kg} \mathrm{m}^{-2}$ of citrus pulp; plots $\mathrm{C} 1=$ soil amended with $9 \mathrm{Kg} \mathrm{m}^{-2}$ of citrus pulp.

the results of Trevisan et al. (1999) could be due to the fact that, in our case, soil moisture was maintained at field capacity by irrigation while in the cited experiment, the soil was subject to a long, dry period. In fact, the Authors themselves observed that soil moisture plays an important role in the rate of aclonifen degradation.

\subsection{Aclonifen degradation in the laboratory}

The degradation of aclonifen in laboratory studies was a first-order reaction in both soils $\left(\mathrm{r}^{2}>\right.$ $0.98)$. The $\mathrm{DT}_{50}$ of aclonifen were 30 and 13 days in soils $\mathrm{A}$ and $\mathrm{C}$ respectively and are lower than those obtained by Vischetti et al. (2002) in a sandy-clay loam soil maintained at similar temperature and moisture conditions (40.3-49.1 days). This difference could be due to the fact that they performed the degradation studies on a soil stored in air-dried conditions. The con- 


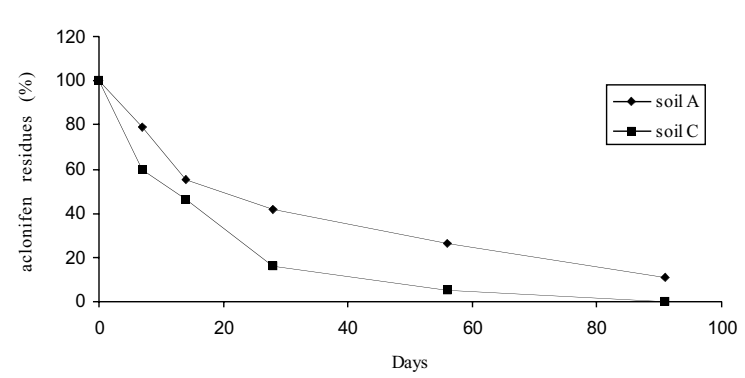

Figure 1. Degradation kinetics of aclonifen in amended and unamended soils: field test. Plots A1 = unamended soil; plots $\mathrm{B} 1=$ soil amended with $3 \mathrm{Kg} \mathrm{m}^{-2}$ of citrus pulp; plots $\mathrm{C} 1=$ soil amended with $9 \mathrm{Kg} \mathrm{m}^{-2}$ of citrus pulp.

servation of the soil in dry conditions could have partially compromised the activity of the soil microrganisms.

With temperature of $20{ }^{\circ} \mathrm{C}$ and $16 \%$ soil moisture, Trevisan et al. (1999) found a $\mathrm{DT}_{50}$ for aclonifen of 27.2 days, a time similar to that highlighted in our experiment in soil A.

As compared to the field tests, the laboratory tests demonstrated a greater persistence of aclonifen in soil $\mathrm{A}$ while in soil $\mathrm{C}$ the half-life time appeared similar. Probably, the addition of organic matter meant that the soil microflora adapted better to laboratory conditions.

\section{Conclusions}

The amendment fostered both luxuriant vegetation and achenes production in sunflowers. On the contrary to what was found when studying the effects of this amendant on the growth and production of durum wheat, the higher quantity of citrus pulp did not have any negative effects on the yield while it stimulated luxuriant vegetation. The lowest quantity of citrus pulp produced the maximum $\mathrm{AE}$; nonetheless, if it was necessary to dispose of higher quantities of this organic matter, the quantity equal to $9 \mathrm{~kg}$ $\mathrm{m}^{2}$ could also be used without compromising the productive results of this crop.

The degradation of aclonifen was not affected by the addition of citrus pulp in field conditions while it induced an acceleration in laboratory conditions. Most probably the laboratory test highlighted better the positive effect of the amendant on the microbial activity of the soil.

\section{References}

Correia Guerriero C., Carrasco de Brito J. 1995. Re-use of industrial orange wastes as organic fertilizers. Bioresource Technol., 53:43-51.

Avola G., Tuttobene R., Abbate V. 2004. Effetti dell'interramento di pastazzo agrumario essiccato sulla crescita e la produzione di frumento duro (Triticum durum desf). In: Valorizzazione di acque reflue e sottoprodotti dell'industria agrumaria e olearia, 249-260. Laruffa, Reggio Calabria, Italy.

Belligno A., Di Leo M.G., Marchese M., Tuttobene R. 2005. Effects of industrial orange wastes on soil characteristics and on growth and production of durum wheat. Agron. Sustain. Dev., 25:129-135.

Garcìa C., Hernàndez T., Roldan A., Albadalejo J., Castello V. 2000. Organic amendment and mycorrhizal inoculation as a practice in afforestation of soils with Pinus halepensis Miller: effect on their microbial activity. Soil Biol. Biochem., 32:1173-1181.

Anastasi U., Cammarata M., Abbate V. 2000. Yield potential and oil quality of sunflower (oliec and standard) grown between autumn and summer. Ital. J. Agron., 1:23-36.

Bellin C.A., O’Connor G.A., Jin Y. 1990. Sorption and degradation of pentachlorophenol in studge-amended soil. J. Environ. Qual., 19:603-608.

Baskaran S., Bolan N.S., Rahman A., Tillman R.W. 1996. Effect of exogenous carbon on the sorption and movement of atrazine and 2,4-D by soil. Aust. J. Soil Res., 34:609-622.

Abdul, A.S., Gibson T.L., Rai D.N. 1990. Use of humic acid solution to remove organic contaminants from hydrogeologic systems. Environ. Sci. Technol., 24:238333.

Celis R., Barriuso E., Houot S. 1998. Sorption and desorption of atrazine by sludge-amended soil: dissolved organic matter effects. J. Environ. Qual., 27:1348-1356.

Covarelli G. 1999. Controllo della flora infestante. Le principali colture agrarie. In: Edagricole. Edizioni Agricole. Bologna, Italy.

Vischetti C., Marucchini C., Leita L., Cantone P., Danuso F., Giovanardi R. 2002. Behaviour of two sunflower herbicides (metobromuron, aclonifen) in soil. Eur. J. Agron., 16:231-238.

Trevisan M., Capri E., Cella A., Errera G., Sicbaldi F. 1999. Field, laboratory and modelling studies to evaluate acolifen soil fate. Toxicol. Environ. Chem., 70:29-47.

Assessorato all'Ambiente della Regione Piemonte, Metodi di analisi dei compost. 1998. Collana Ambiente, 6. Arti Grafiche LCL Busca, Cuneo, Italy.

Alianello F., Baroccio F. 2001. Caratterizzazione di residui agroindustriali mediante focalizzazione isoelettrica. Proceedings of Convegno Nazionale Società di Chimica Agraria, 25-28 September, Reggio Calabria, Italy, 7-14. 
Garcìa C., Hernandez T., Costa F., Ceccanti B., Ciardi C. 1992. Changes in ATP content, enzyme activity and inorganic nitrogen species during composting of organic wastes. Can. J. Soil Sci., 72:243-253.

Cartabellotta D., Drago A., Lo Bianco B., Lombardo M. 1998. Climatologia della Sicilia. Regione Siciliana Assessorato Agricoltura e Foreste - Gruppo IV Servizi allo Sviluppo - Unità di Agrometeorologia, Palermo, Italy, 3:245.

Mariotti M., Masoni A., Ercoli L. 2000. Distribuzione dei fanghi di cantina alla soia. Nota I. Accrescimento epigeo ed ipogeo. Riv. Agron., 34:227-233.

Laskowsky D.A., Swann R.L., MacCall P.J., Bidlack H.D. 1983. Soil degradation studies. Residue Rev., 85:139147.

Gennari M., Cignetti A., Nègre M. 1986. Evaluation of a laboratory method to determine the behaviour of pesticides in soil. Abstracts of Papers, Sixth Interna- tional Congress of Pesticide Chemistry, August, Ottawa, Canada, 6B-20.

Katerji N., van Hoorn J.W., Hamdy A., Mastrorilli M. 2003. Salinity effect on crop development and yield, analysis of salt tolerance according to several classification methods. Agr. Water Manage., 76:24-35.

Kahlown M.A., Ashref M., Zia-ul-Haq. 2005. Effect of shallow groundwater table on crop water requirements and crop yield. Agr. Water Manage., 76:24-35.

Anastasi U., Cammarata M., Sortino O., Abbate V. 2001. Comportamento agronomico e composizione lipidica degli acheni di due ibridi di girasole (convenzionale e ad alto oleico) in risposta ai fattori ambientali. Riv. Agron., 35:76-86.

Meli S.M., Baglieri A., Porto M., Belligno A., Gennari M. 2007. Chemical and microbiological aspects of soil amended with citrus pulp. J. Sustain. Agr., in press. 